\title{
Politics and Ethic of Care of the Self in Albert Camus's The Plague
}

\author{
Mukesh Kumar Bairva \\ Assistant Professor \\ Department of English \\ Pannalal Girdharlal Dayanand Anglo Vedic \\ University of Delhi \\ New Delhi, India \\ englitt105@gmail.com
}

Abstract

Albert Camus' The Plague articulates a new aesthetic of existence that resists biopolitical normalization. It means cultivating one's self and not attempting to discover an authentic and hidden self because it entails a continual process of becoming. The sudden eruption of plague in Oran, signifies a rupture in history of its people as the "bored populace is consumed by commercial habits aimed at making money". In The Plague, if some people become more self-centred and insensitive, characters such as Rieux, Rambert, Peneloux and Joseph Grand show concern for the suffering people and stand in solidarity with them. Their characterization as ordinary individuals who assume responsibility for others' existence in times of disaster reflects Camus' hermeneutic of care of the self as an ethical project. Camus aptly asserts that "ordinary acts of courage and kindness are more helpful than the illusion of superheroes". Deriving a cue from Foucault, Heidegger and Levinas, the paper attempts to explore how care of the self is intertwined with ethics and politics. It is argued that without spiritual discipline and caring for others, the ethical transformation of self cannot take place. It indicates fashioning of the self more freely and self-reflexively and thus speaking truth to 
power and sacrificing for others. The paper examines this poetics of self which shares an ethical relationship with truth, freedom and kindness.

Keywords: Care, Self, Truth, Compassion, Existence, Hermeneutic And Ethics

Albert Camus's brilliance as a writer lies in his ability to delineate human suffering with its vehemence. In his novel ThePlague, suffering dominates as a kernel of human existence. He not only portrays physical suffering also delineates mental agony. Suffering pushes people to their edge and bring them into a state of despair and hopelessness. Existentially, we face both happiness and sorrow. Camus underscores that people from all classes and identities are exposed to suffering. However, people who are privileged have more resources to latch onto when a crisis enters into their life. Every epidemic or pandemic exposes whether a society has a culture of care, compassion and truth or not. The outbreak of novel corona virus (Covid-19) has exposed this truth vividly. Camus' novel The Plague underlines that life is full of absurdity and people need to rebel against the absurd to fill their life with meaning. The bourgeois life of the citizens of Oran produces this absurdity. They were living a comfortable and normal life before the outbreak of the epidemic. However, the sudden arrival of plague in Oran causes an ontological and epistemological crisis. Itsignifies a rupture in history of its people as the bored populace is consumed by their materialistic and commercial habit of minting money.The epidemic destabilizes the regularity of life in Oran. It devastates the citizens of Oran physically, psychologically and spiritually. The paper proposes that in the actions of Dr. Rieux, Rambert, Tarrou and Peneloux, we can read Foucauldian-Heideggerian and Levinasian enunciation of the politics and ethic of care of the self.

Michele Foucault refers to the ancient Greeks and Romans to theorize the ethic of care. He argues that ancients regarded care of the self as the basis of moral rationality. It was a precept of living. (Ethics, 94). The practice of self is a permanent battle. Care of the self has 
a curative and therapeutic function. We must be strong enough to stand up against events and not to be overwhelmed by the emotions that may arise in us. (Foucault, 99). For the ancients, care of self was not just about paying attention to oneself but also to show concern for others as well. He alludes to the association of the care of the self with politics, pedagogy and selfknowledge. (Ethics, 95). The idea of care, postulated by Socrates, meant caring for one's soul and for others' by examining his own conduct and that of his interlocutors.

For Foucault, care of the self indicates ethical transformation of self in the light of truth.(Iftode, 79-80). It is a kind of spiritual exercise which requires self-reflection, meditation and discipline and regulation of one's conduct. He draws upon the idea of parrhesia (which means to say express the whole truth) articulated in the antiquity in relation to the care of the self. Parrhesia needs courage to tell truth to power and it can be read as polar opposite of rhetoric. A parrhesiat is a courageous teller of truth who takes risk whereas a rhetorician is a glib talker. (Franek, 119). Expounding the relation between self and truth, Foucault specifies that it does not imply discovering some hidden truth rather the aim is to equip the subject with truth it was not aware of and to put it into practice. (Ethics, 100). He defines ethics as conscious practice of freedom. He writes: "freedom is the ontological condition of ethics" (Ethics, 284). The theme of care of the self was anchored in moral reflection. He opines that care for oneself was not denounced as a form of self-love or a form of selfishness. In fact, it emerged during Christianity as it prescribes that salvation is possible only through renunciation of the self. But for the Greeks and Romans, care of the self was required for proper conduct and practice of freedom. Not to be a slave was a prerequisite for the formation of self. To know oneself, to master oneself and care of the self are interrelated. The notion of ethic as conscious practice of freedom centred around the theme "Take care of yourself". (Foucault, 285). Ethics is a mode of being and behaviour. It is a reflective part of freedom. That's why Foucault opines that a slave possesses no ethics. Freedom is inherently 
political. (Ethics, 286). In this way politics and ethic are related. Moreover, the care of the self is ethical in itself. It means complex relationships with other human beings as the ethos of freedom is a method of caring for others. Without taking care of oneself, one is consumed by one's desires and thus arises the risk of dominating others. Care of the self makes it incumbent upon oneself to know oneself ontologically who one is and to know what it means to be citizen of a nation. Caring for others in the Foucauldian scheme of things hinges on the care of the self.

Heidegger also drew upon the concepts of being and care (sorge). For him, the meaning of Being is expressed in human action. Being makes it possible to understand oneself. It is linked to ethical practice of Being-in-the world. His ethics of authentic selfunderstanding rests on the practice of understanding oneself fully by caring for other beings in the world. (Mcnicolls, Self-Understanding and the Care for Being: Heidegger's Ethical Thought 4). His understanding of being is similar to Foucault's notion of care of the self as a mode of being. The idea of 'Being' enables us to decipher ourselves ontologically and also to make sense of others. One has the freedom to understand oneself in a certain way, in other words, to care for others and things in a particular way. Understanding oneself in a certain way makes it necessary to engage others in a certain way. His concept of 'Being' is central to our ontological decipherment and it is ethically articulated through our actions. And the meaning of 'Being' is reflected in way we care for others and the expression of our solidarity with them. It means we cannot have authentic understanding of ourselves without caring for other beings and engaging with them.

Heidegger's concept of 'Being' lays emphasis on the experience of human finitude and our relation to death. Our experience of finitude is helpful in caring for others in a more concrete way. Our anguished relation to death offers us a broader understanding of the world and inculcates in us a deeper level of solidarity with others. So, the realization of our being 
finite beings is pivotal to develop an ethic of care for others. Heidegger underlines that the Being refers to the Being- in- the- world which means Being in relation to others. When an epidemic strikes or the threat of war looms large over us, we experience a sense of finitude and anguish. The current pandemic (Covid-19) has given us an occasion to understand how we are limited by time and space and thus the knowledge dawns upon us that the meaning of life lies in caring for and displaying solidarity with other fellow beings. Nonetheless, we can share solidarity with others without surrendering our individual identity and freedom. Alberoni calls it "alternative form of solidarity" (Movement and Institution 20). The notion that authentic being entails concern for others revolutionizes the idea of individual autonomy. In fact, to care for others and preserving our individual autonomy simultaneously shows our creativity. Actually, to exist authentically we need our permanent anguished and critical relation with the social present. The Being of Dasein as Being-in-the world is predicated upon the notion of care. (Mulhall 2005). The Levinasian hermeneutic of self and care is also relevant here. In his framework, care and autonomy are interrelated. Levinas opines: "Caring seems to involve taking concerns and need of the other as the basis for action... what is definitive about care... seems to a perspective of taking the other's needs as the starting point for what must be done." (qtd. in Tronto 105). He deconstructs the totalizing and Darwinistic frames of the Western thought which reduces the other to an object for reflection. Selfpreservation without concern for the other is a Darwinistic value. However, Levinasian ethic of care calls for defying this rule of being."The content of the other's instruction is ethical." (Dietrich et al. 43). We learn dialogically through other's action and response.We inhabit this world with others. We may not immediately know. But we have an ethical obligation to the other who may not be present at the moment. The entire equation of the self-other also changes; we also become the other in others' intellectual categories. (Levinas 213). He elaborates that personal responsibility is determined by our responsibility to others. We 
become important in the ethical frame only in relation to the other. Ethics exists outside the realm of being. It keeps us at bay from the fetters of egoism. The other offers us a possibility of living outside the labyrinthine circuits of our own interiority. The Levinasian ethic of care is inextricably intertwined with liberation which does not take place in isolation from the human community. It does not happen in the mystical space of a cloistered saint. Rather it becomes possible through human dialogue and within our responsibility to others. Tronto and Levinas agree to the issue of using justice as an instrument to promote the ideas of care and responsibility for others. (Dietrich et al. 50-51). So, Levinas' notion of responsibility for others entails the concept of ethic of care. For him, responsibility is not something that we fulfil consciously; in fact, we are confronted with it in spite of ourselves. His care ethic postulates that care is a love that I cultivate only with labour.

The portrait of Oran by Camus in The Plague is extremely signifying. He paints it as ugly and thoroughly negative. It is marked by smug and placid air. It is bereft of natural beauty. It remains untouched by the change of seasons. The ambience of Oran exteriorizes the banality of the citizens of this town.The way the people of Oran live, love and die indicates a terrible sense of absurdity. Camus observes: "The Truth is that everyone is bored, and devotes himself to cultivating habits. Our citizens work hard but solely with the object of getting rich.” (The Plague 2). It is an ugly, glamour less and soulless town where banality is the defining characteristic of human existence. The self-absorbed citizens of Oran never imagined that their'normal' would be turned upside town.

In the wake of the plague, the gates of Oran are closed and it gets isolated from other towns. The infected people are also isolated. The pulsating life comes to a sudden halt. Cinema halls and restaurants are closed; all trade and commercial activities are stopped. All kinds of communication and transport except telegraphic messages are stopped. People are separated from their loved ones. The entire town is gripped by crippling anxiety and nihilism. 
People react differently to the tragedy caused by the plague. The epidemic has had a profound impact on the people's mind. Some people become hedonists and others behave insanely. The fear of plague force people to avoid human contact which cause further isolation and despair. In the wake of covid-19, some subaltern groups faced a resurgence of contempt and prejudice all over the world. For instance, an attempt was made to construct an abominable subject. Fascist math was used to stereotype the minoritarian subject. The case of Tablighi Jamaatis was employed as a pretext to demonize the entire Muslim community in India and they were blamed and targeted for the spread of the pandemic. Cataclysmic events bring out the best and the worst in us. On the one hand, social Darwinism dominates people's consciousness, simultaneously, on the other hand, it produces site and space for formation of a new subjectivity characterized by compassion, courage and truth. The Plague articulates a new aesthetic of existence that resists biopolitical normalization. With the arrival of the epidemic, the citizens of Oran become more selfish and centred and distance themselves from other citizens due to the fear of infection, but some individuals such as Dr. Bernard Rieux, RayomondRambert, Tarrou and Father Peneloux show exemplary courage and kindness to help the suffering individuals and fight against the devastating epidemic. Even the government of Oran does not show any gestures of sympathy for the people. Dr. Rieux takes help of his friend, a clerk in the municipal department, to apprise the administration of the gravity of the situation. But his efforts to alert the administration about the possibility of the eruption of a major epidemic also go futile. It continues to ignore the signs of imminent threat. As a result, it turns out to be a catastrophe.

Rieux believes that by caring for all we can build a better world. It reminds us of Joan Tronto's view:

On the most general level, we must suggest that caring can be viewed as a species activity that includes everything that we must do to maintain, continue, and repair our 
'world' so that we can live in it as well as possible. That world includes our bodies, our selves, and our environment, all of which seek to interweave in a complex, lifesustaining web.(Moral Boundaries 103).

The ethic of care functions as a litmus test through which we can assess the ethical quality of people's actions. It can work as a supplemental guide to the already existing framework of justice. Even Aristotle holds that political life can be a tool of realizing moral principles and vice-versa. (Diedrich et al. 37-38). When all the citizens of Oran lose hope and begin to descend into anguish, Dr. Rieux, Rambert, Tarrou and Father Peneloux refuse to be intimidated by the enormity of the tragedy. Of course, in the beginning, they also feel lonely and scared but gradually they grapple with it bravely. Rieux and Rambert get separated from their partners due to the sudden closing down of Oran. Rieux's wife leaves for a sanatorium in the mountains and she is stranded there due to the quarantining of Oran. His devotion and concern for his ailing wife reflects that he is a conscientious individual and a good husband. Interestingly, a theorist of care ethic, Joan Tronto, regards home as the moral ground for care ethic. Rieux qualifies the ordeal of the ethic of care in his private as well as public sphere. An individual's ethic of care is manifest in all his roles. For Rieux politics and morality are not two distinct realms. They intermingle with each-other. His belief is that if the distinction between the morality of the private realm and that of the public realm does not collapse, we cannot transform the world.

Tronto perceives justice as "the continued care for the common good." (Lecture 2003).Rieux attends to the sick and the infected patients in spite of the panic of infection. His care for Cottard and M. Michel is admirable. M. Michel is a porter at his building but Rieux does not discriminate against him. When he falls ill, he devotes a lot of time and energy to cure him Though Michel is infected by plague, Rieux does not afraid and continues to treat him. Even he keeps and treats Tarrou at his home when the latter is infected by plague. He 
motivates Tarrou to courageously face the fear of plague and reminds him that to even become a saint one has to live. In fact, he shared it with him an intellectual kind of relationship. They reflected together on the profound questions pertaining to human existence. In Foucauldian terms, Rieux is a parrhesiat. He has unflinching commitment to truth and care for others. Rieux's stoicism is manifest in the fact that even after knowing about the death of his wife, he does not lose hope and continues to work for the diseased and infected. He grills Rambert whether he would be able to speak truth about the menace of dying rats. Rambert initially experiences deep anguish and loneliness and frantically seeks Dr. Rieux's help to meet his partner. But when Dr. Rieux expresses his inability to offer any succour in this regard, Rambert accuses him of living in abstractions. However, the matter of fact is that he comprehends reality not through abstractions but through human suffering. It indicates that the epidemic has disrupting impact on everybody's mind. Even the people of indomitable will are vulnerable to it. Dr. Rieux also feels exhausted while struggling against the plague. However, those who understand the epidemic attempt to cope with its psychological repercussions more bravely.

He can discern the sign of an epidemic behind the dying rats. In the entire town of Oran, he is the only person who is constantly thinking about this uncanny phenomenon. He inquires about it from everyone he meets. His concern for the poor is indicative of his ethic of care. He treats the poor patients with equal degree of commitment. He does not charge fee from one of his former patients, a clerk in the municipal office. Cottard is a depressed individual who tries to commit suicide. Rieux fully sympathizes with him and tries to cure him so that he can come out of depression. He ensures that police do not harass him, and for that purpose, he remains present with him when the inspector come to complete formalities. Cottard is described as an unfortunate man who is struck by profound grief. The novel demonstrates that people's actions reflect their ethics. Dr. Rieux's struggle to save the 
citizens of Oran from the threat of plague can be categorized as ethical activism. Camus explores the existential themes of love and suffering through the character of Rieux who seeks meaning and hope in this world not the next.

The death of M. Michel marks the end of bewildering portents and the beginning of a new phase where perplexity gives place to panic. It is an alarming sign of a contagion. Dr. Rieux receives call from many people with complaints of high fever and other symptoms of plague. Rats were dying in the street and men in their homes. Castel, one of Rieux's colleagues also hints at the eruption of an epidemic. Camus ponders: "Everybody knows that pestilences have a way of recurring in the world; yet somehow we find it hard to believe in ones that crash down on our heads from a blue sky. There have been as many plagues as wars in history; yet plagues and wars take people equally by surprise" (The Plague 35). He describes that his townsfolk are too obsessed with themselves to pay heed to the occurrence of a pestilence. He further writes that contagion is not a figment of imagination. It is a hard and terrifying reality staring in our face. It is not a bad dream that will disappear. As a matter of fact, it is the men who pass away; first it strikes the humanists like the citizens of Oran, because they do not take precautions. However, Rieux does not ignore his forebodings about a contagion. An incessant fear and unease grips his mind. He recollects what he had read the epidemic. Terrible figures float across his memory that around thirty plagues that happened in history resulted in millions of deaths. He expresses that it is possible to stop it from exploding into an epidemic. Camus hints at the fact that it is foolhardy to wait for superheroes or Gods to whisk away humans from a pestilence. Actually, timely and wise interventions by ordinary men and women can save humanity from grave dangers. His reply to Tarrou carries a significant message. He expresses: "But you know, I feel more fellowship with the defeated than with saints. Heroism and sanctity don't really appeal to me, I imagine. What interests me is- being human." (Camus 245). Through his tryst with struggle of life, he 
has attained the wisdom that to be is to exist inter-subjectively. To be human is to care for others and take part in people's struggle.

As Foucault has aptly said everything is discursive, the outbreak of the plague is also interpreted differently. (Mills 53). Ernesto Laclau and Chantal Mouffe in their book Hegemony and Socialist Strategy also expound how reality is constructed and apprehended through discourse:

The fact that every object is constituted as an object of discourse has nothing to do with whether there is a world external to thought...An earthquake or the falling of a brick is an event that certainly exists, in the sense that it occurs here and now, independently of my will. But whether their specificity as objects is construed in terms of natural 'phenomena' or expressions of 'the wrath' of God depends on the structuring of a discursive field. What is denied is not that such objects externally to thought, but the rather different assertion that they could constitute themselves as objects outside any discursive condition of emergence. (Hegemony and Socialist Strategy 108).

Tarrou observes: "I can say I know that world inside, as you may see-that each of us has the plague with in him; no one on earth, is free from it." (Camus 242). He tries to interpret plague as a metaphor for evil or sin. He argues further that there are pestilences and victims on this earth and it is up to us choose as to where we want to stand. What he implies is that the world is full of injustice and deprivation. It hinges on our will whether to go with justice or injustice. We should try as far as possible to join forces with truth and justice, thus, with the side of victim. Camus' The Plague articulates this kernel of truth. It puts forth a new aesthetic of existence where ordinary human beings need to support the weak and marginalised individuals. The Christian authorities view the plague from religious hermeneutic. Father Peneloux, while giving sermon to people, describes it as God's 
punishments upon people for their sins and he opines that this suffering will lead their redemption. He warns:

For plague is the flail of God and the world His threshing -floor and implacably He will thresh out His harvest until the wheat is separated from the chaff. There will be more chaff than wheat, few chosen of the many called. Yet this calamity was not willed by God. Too long this world of ours has connived at evil, too long has it counted on the divine mercy, on God's forgiveness (Camus 91).

While Rieux carries a diametrically opposite view of the entire event. In his conversation with Tarrou, he discloses that he does not believe in God. He remarks: "If he believed in an all-powerful God would cease curing the sick and leave that to Him. But no one believed in a God of that sort; no, not even Peneloux, who believed that he believed in a such a God. And that is proved by that fact that no one ever threw himself on Providence completely." (Camus 122). Rieux developed this atheistic conviction from his struggle with life and the comprehension of suffering. In his profession, a doctor is regarded a saviour by people as he fights against death while curing the sick. He is determined to face a "neverending defeat"(Camus 124) but won't resign to a whimsical or fatalistic idea of life. His aesthetic of existence is grounded in this existential reality as he has seen immense pain, deprivation and despair. While talking to Peneloux, he asserts: Salvation is much too big a word for me. I don't aim for high. I am concerned with man's health; and for me health comes first." (Camus 209). He knows that equality, health, food, fraternity and freedom are politically determined questions. Tarrou, Rieux and Rambert engage in philosophical speculations about life. Rambert maintains that people die for what they love. Rieux risks his life because of his commitment to humanity. His relentless work for the victims of the plague transforms individuals like Rambert, Tarrou and M. Othon. They too join Rieux's revolutionary campaign to save people's lives. M. Othon, the magistrate, decides to stay back 
in the camp though he is declared fit after the period of quarantine. His son's death changes his worldview. He realizes that one finds peace only through the path of sympathy for others. Selfishness and obsession with power makes one lonely and forces in perpetual selfimprisonment. Father Peneloux reinterprets the message of Christianity after seeing people's pain and death in the ordeal of the plague. He asks: For who would dare to assert that eternal happiness can compensate for a single moment's human suffering? He who asserted that would not be a true Christian, a follower of the Master who knew all the pangs of suffering in his body and his soul." (Camus 214). He understands that words such as 'salvation'or 'eternal happiness' are empty words without expressing solidarity with the suffering humanity. Thus, we can conclude that the novel revolves round the politics and ethic of care. It invents a different politics of care where the precariat and the suffering of humans constitute the main concern. When the gates of Oran are opened, people celebrate and enjoy. However, Camus posits that the threat of plague never disappears forever. He articulates a warning message:

That the plague bacillus never dies or disappears for good; that it can lie dormant for years in furniture and linen-chests; that it bides its time in bedroom, cellars, trunks and bookshelves; that perhaps the day would come when, for the bane and the enlightening of men, it roused up its rats again and sent for to die in a happy city. (Camus 296).

What he gestures towards is that evil never dies for good and struggle defines human life. Metaphorically speaking, if one totalitarian regime collapses, it does not imply that it cannot be replaced by another similar regime. At the end when Camus reveals that Rieux is the narrator, the latter explains as to why he decided to chronicle all the events. He mentions that he wished history to bear witness in favour of the oppressed and the plague-stricken people. Rieux's politics of care propels him to record and archive truth so that the memorial of 
injustice and outrage may be preserved. For justice to be secured, truth needs to be consciously protected and presented. Truth is linked in a circular relation with systems of power which produce and sustain it". (Foucault 133). Truth is something which societies have to work hard to produce; it does not appear in a transcendental way. His ethic of care is most clearly visible in his statement "to state quite simply what we learn in a time of pestilence: there are more things to admire in men than to despise." What he underscores is man is immensely capable of compassion, love, and sympathy even in the times of epidemics. So, the experience of the plague familiarizes with the notion that man is not intrinsically evil or cruel. The values of compassion, equality and love can be inculcated in man.

In conclusion, it can be said that the politics and ethics of care in Camus' The Plague does not uphold the liberal political view because in liberalism the ultimate end is to seek freedom from the obstructing concerns of the other. Camus argues for ethical freedom in which civic duty and the sense of responsibility for others constitute the idea of liberty. The origin of caring lies outside the self- in the transcendence of the oppressive in-dwelling so the actions of caring do not not ask for valorization. Care and responsibility are not abstract terms; they exist only in practicing and doing them. 


\section{Works Cited}

“Albert Camus' The Plague: A Story for Our and All Times”. The Guardian

https://www.theguardian.com/booksblog/2015/jan/05/albet-camus-plague-fascistdeath-ed-vulliamy. Web. 22nd Oct 2020.

Alberoni, Francesco. Movement and Institution. Trans. Patricia C. Arden Delmoro. New York: Columbia University Press, 1984.

Diedrich, Wolf W, et al. Towards a Levinasian Care Ethic: A Dialogue between Thoughts of Joan Tronto and Emmanuel Levinas. Web 12 November 2020. http://www.ethics.be/ethics/viewpic.php?LAN=E\&TABLE=EP\&ID=963.

Franek, Jakub. "Philosophical Parrhesia as Aesthetic of Existence". Continental Philosophy Review (2006) 39: 113-134. Web. 30 June 2020.

Iftode, Cristian. "Foucault's Idea of Philosophy as 'Care of the Self': Critical Assessment and Conflicting Meta-Philosophical Views". Procedia-Social and Behavioral Sciences 71 (2013) 76-85. Web. 6 July 2020.

Levinas, Emmanuel. Totality and Infinity: An Essay on Exteriority. Duquesne Studies: Philosophical Series 24. Pittsburg, PA: Duquesne University Press, 1969.

Mcnicolls, Christopher Ferdinand. Self-Understanding and the Care for Being: Heidegger's Ethical Thought. A Thesis. McMaster University, 1998.

Sara Mills. Michel Foucault. London and New York: Routledge, 2003. p.53.

E. Laclau and C. Mouffe. Hegemony and Socialist Strategy: Toward a Radical Democratic Politics. Second Edition.London: Verso, 2001.

Mulhall, Stephen. Heidegger and Being and Time. London and New York: Routledge, 2005. Print.

Tronto, Joan. Moral Boundaries: A Political Argument for an Ethic of Care. London and New York: Routledge, 1994. 
----. "Beyond Gender Difference to a Theory of Care: Care, Ethics and Politics". Lecture, 14 March 2003. Leuven Katholieke Unversitieit Leuven, Belgium. 